INFLAMMATORY BOWEL DISEASE

\title{
Influence of intestinal bacteria on induction of regulatory $T$ cells: lessons from a transfer model of colitis
}

\author{
U G Strauch, F Obermeier, N Grunwald, S Gürster, N Dunger, M Schultz, D P Griese, \\ M Mähler, J Schölmerich, H C Rath
}

See end of article for authors' affiliations

Correspondence to: Dr U G Strauch, Department of Internal Medicine I, University of Regensburg, D-93053 Regensburg, Germany; Ulrike.Strauch@

klinik.uni-regensburg.de

Revised version received 8 June 2005

Accepted for publication 10 June 2005

Published online first

29 June 2005

Background: The resident flora plays a critical role in initiation and perpetuation of intestinal inflammation, as demonstrated in experimental models of colitis where animals fail to develop disease under germ free conditions. However, the importance of exposure to commensal bacteria before the onset of colitis is unclear. Our aim was to investigate the influence of previous exposure of donor animals to bacterial antigens on colitis development using a transfer model.

Methods: Clinical course and histology were evaluated after transfer of $\mathrm{CD}^{+} \mathrm{CD} 62 \mathrm{~L}^{+}$lymphocytes from germ free and conventionally housed donor mice into SCID recipients. Cotransfer of $\mathrm{CD4} 4^{+} \mathrm{CD} 62 \mathrm{~L}^{+}$cells with $\mathrm{CD} 4{ }^{+} \mathrm{CD} 62 \mathrm{~L}^{-}$lymphocytes from both groups of mice was initiated. Lymphocytes were analysed by FACS, polarisation potential of cells determined, and cytokines measured within the supernatant by enzyme linked immunosorbent assay.

Results: Animals that received cells from germ free donors developed an earlier onset of colitis compared with mice reconstituted with lymphocytes from conventionally housed animals. Additionally, $\mathrm{CD} 4^{+} \mathrm{CD} 62 \mathrm{~L}^{-}$ cells from germ free mice were not able to abrogate colitis induced by cotransfer with $\mathrm{CD} 4^{+} \mathrm{CD} 62 \mathrm{~L}^{+}$ lymphocytes whereas $C D 4^{+} \mathrm{CD} 62 \mathrm{~L}^{-} \mathrm{T}$ cells from normal mice ameliorated disease. The higher percentage of $\mathrm{CD}^{+} \mathrm{GITR}^{+}$expressing lymphocytes and the production of interleukin 10 after priming by dendritic cells suggests the presence of $\mathrm{T}_{\text {reg }}$ cells within the $\mathrm{CD} 4^{+} \mathrm{CD} 62 \mathrm{~L}^{+}$lymphocyte subset derived from conventional housed mice and assumes a lack of $\mathrm{T}_{\text {reg }}$ cells within germ free mice.

Conclusion: The results indicate that bacterial antigens are crucial for the generation and/or expansion of $\mathrm{T}_{\text {reg }}$ cells in a healthy individual. Therefore, bacterial colonisation is of great importance in maintaining the immunological balance.

l: flammatory bowel diseases (IBD) are chronic inflammatory conditions of the intestine of still unknown aetiology. However, analysis of a wide variety of mouse models of intestinal inflammation resembling IBD has led to major advances concerning the immunopathology of chronic colitis. ${ }^{1-3}$ Recently, experimental models have helped to establish a crucial role for the microbial flora in induction and perpetuation of colitis and suggested that gut inflammation results from a dysregulated immune response towards bacterial antigens. ${ }^{4-6}$ Various reports demonstrated the presence of $\mathrm{T}$ lymphocytes with specific reactivity towards bacterial antigens within animals with colitis that were able to transfer inflammation to healthy animals. ${ }^{7}$ Also, in humans, bacteria reactive T lymphocytes were more frequent in patients with IBD than in healthy individuals. ${ }^{8}$ Therefore, it has been speculated that a breakdown of tolerance towards the intestinal bacterial microflora may play a role in the pathogenesis of IBD. ${ }^{9}$

However, microflora reactive $\mathrm{T}$ cells with regulatory function have also been found within the colon of specific pathogen free interleukin (IL)-2-deficient mice that develop spontaneous colitis. This observation suggests that commensal bacteria do not only play a role in the pathogenesis of colitis but also within the generation of anti-inflammatory mechanisms in mucosal tissues. ${ }^{10}$

An important model to study the role of pathogenic T cells in the development of colitis was established previously. Here, transfer of predominantly naïve $\mathrm{CD} 4^{+} \mathrm{CD} 45 \mathrm{RB}^{\text {high }}$ lymphocytes into $\mathrm{T}$ and $\mathrm{B}$ cell deficient mice induces severe inflammation within the colonic mucosa of the recipient, resembling IBD-like lesions. ${ }^{11}$ The transferred T cells proliferate within the lymphopenic host and lead to excessive colitis inducing effector $\mathrm{Th}_{1}$ cell responses that can be prevented by cotransfer of mature $\left(\mathrm{CD} 4^{+} \mathrm{CD} 45 \mathrm{RB}^{\text {low }}\right)$ cells thought to contain regulatory lymphocyte $\left(\mathrm{T}_{\text {reg }}\right)$ subpopulations. ${ }^{11} 12$ As described for various other experimental colitis models, ${ }^{5}{ }^{13-16}$ bacterial antigens play a role, as only mild colitis develops when $C D 4^{+} \mathrm{CD} 45 \mathrm{RB}^{\text {high }} \mathrm{T}$ cells are transferred into animals with a restricted enteric flora and no intestinal inflammation is observed after transfer into germ free mice. ${ }^{17}$ Although there is overwhelming support for the hypothesis that chronic intestinal inflammation is triggered by enteric bacteria within the recipient animal, the specific antigen(s) that drives the immune response has not yet been identified..$^{18}$ Moreover, it is still unclear whether previous exposure of lymphocytes to bacterial antigens within the donor animal influences the development or severity of intestinal inflammation after transfer.

The aim of the present study was therefore to investigate the role of previous priming of lymphocytes by immune responses towards bacterial antigens on induction of colitis in

Abbreviations: IBD, inflammatory bowel disease; GF, germ free; $B M-$ $D C$, bone marrow derived dendritic cells; $M L N$, mesenteric lymph node; GITR, glucocorticoid induced tumour necrosis factor receptor related protein; TNF- $\alpha$, tumour necrosis factor $\alpha$; IL, interleukin; IFN- $\gamma$, interferon $\gamma ; \mathrm{mAbs}$, monoclonal antibodies; ELISA, enzyme linked immunosorbent assay; TGF- $\beta 1$, transforming growth factor $\beta 1$; RT-PCR, reverse transcription-polymerase chain reaction 
an adoptive transfer system using donor cells isolated from germ free or conventional housed animals.

\section{METHODS \\ Mice}

$\mathrm{Balb} / \mathrm{c}$ mice and scid mice (CB-17 SCID) $\left(\mathrm{H} 2^{\mathrm{d}}\right)$ were obtained from Charles River (Germany). Animals were housed under conventional animal facility conditions and were generally used at 6-8 weeks of age. Balb/c mice for the germ free (GF) colony were introduced and maintained in a GF environment at the Central Animal Facility of the Medical School Hannover. GF mice were maintained under sterile conditions in autoclaved plastic microisolator cages with filtered air and received sterile food and water until just before sacrifice. The colony was regularly tested for bacterial contamination by culture of fresh faeces. For the experiments, age matched female mice from the germ free and regular colony were used.

\section{Monoclonal antibodies}

The following experimental monoclonal antibodies (mAbs) were purchased from BD Pharmingen (Heidelberg, Germany): anti-CD8 (53-6.7), anti-MHC-II (2G9), antiCD45R/B220 (RA3-6B2), anti-CD1lb (Ml/70), anti-CD3 (145-2C11), anti-CD28 (37.51), anti-CD152 (CTLA-4; UC102F10-11), anti-CD25 (PC61), anti-CD69 (H1.2F3), and antiCD16/CD32 (2.4G2). PE or FITC conjugated mAbs were used for FACS analysis. The glucocorticoid induced tumour necrosis factor receptor related protein (GITR)/TNFRSF18 (108619) antibody was obtained from R\&D Systems (Wiesbaden, Germany).

\section{CD4 ${ }^{+}$CD62 $\mathrm{L}^{+}$transfer model of colitis}

In order to avoid time consuming FACS sorting to obtain $\mathrm{CD} 4^{+} \mathrm{CD} 45 \mathrm{RB}^{\text {high }} \mathrm{T}$ cells, we adapted a previously described transfer model that uses expression of L-selectin (CD62L) to select via immunomagnetic cell separation for naïve splenic $\mathrm{T}$ lymphocytes. The purity of the transferred $\mathrm{CD}^{+}$and $\mathrm{CD}^{+} \mathrm{CD}_{2} \mathrm{~L}^{+}$cell populations ranged from $93 \%$ to $98 \%$ and lymphocytes expressed high levels of CD45RB. As shown previously, cotransfer of the $\mathrm{CD} 4{ }^{+} \mathrm{CD} 62 \mathrm{~L}^{-}$subset prevented almost completely the development of colitis and the transfer model resembles the $\mathrm{CD} 4^{+} \mathrm{CD} 45 \mathrm{RB}{ }^{\text {high }}$ model regarding cell population, dynamics, and severity of colitis development. ${ }^{19}$

In brief, $\mathrm{CD}^{+} \mathrm{T}$ cells were purified from spleen mononuclear cells of healthy mice housed under GF or conventional conditions by negative depletion of other cell types using anti-CD8, anti-MHC-II, anti-B220, and anti-CD1lb mAbs and anti-rat-IgG immunomagnetic microbeads (Miltenyi Biotech, Bergisch Gladbach, Germany). The resulting $\mathrm{CD}^{+}$lymphocytes were separated further into $\mathrm{CD}^{+} \mathrm{L}^{+}$ and $\mathrm{CD}^{-} 2 \mathrm{~L}^{-} \mathrm{T}$ cells by $\mathrm{CD} 62 \mathrm{~L}$ conjugated microbeads (Miltenyi Biotech). Recipient SCID mice were reconstituted with $0.25 \times 10^{6} \mathrm{CD}^{+} \mathrm{CD} 2 \mathrm{~L}^{+}$lymphocytes in $200 \mu \mathrm{l}$ of sterile phosphate buffered saline by intraperitoneal injection. For cotransfer experiments, $0.25 \times 10^{6} \mathrm{CD}^{+} \mathrm{CD} 2 \mathrm{~L}^{+}$lymphocytes from conventional housed donor mice were administered together with $0.25 \times 10^{6} \mathrm{CD}^{+} \mathrm{CD} 62 \mathrm{~L}^{-}$cells derived from GF or conventional housed animals. Additionally, for initial experiments, transfer of whole splenic $\mathrm{CD} 4^{+} \mathrm{T}$ cells was carried out together with transfer of $\mathrm{CD} 4^{+} \mathrm{CD} 62 \mathrm{~L}^{+}$lymphocytes. Colitis activity was monitored by changes in weight over time and by histological analysis, as specified below.

\section{Coculture of $\mathrm{BM}-\mathrm{DC}$ and $\mathrm{CD} 4{ }^{+} \mathrm{CD} 62 \mathrm{~L}^{+}$splenic lymphocytes}

Bone marrow derived dendritic cells (BM-DC) were generated as described previously. ${ }^{20}$ Briefly, bone marrow was flushed from femurs and tibiae of normal Balb/c mice and cells were cultured for 10 days with medium (RPMI, 10\% fetal calf serum) containing $200 \mathrm{U} / \mathrm{ml}$ GM-CSF (Peprotech/ Tebu, London, UK). For maturation, BM-DC were stimulated subsequently overnight with $5 \mu \mathrm{g} / \mathrm{ml}$ of phosphothioate stabilised CpG-ODN with the following sequence: ODN1668 5'-TCC ATG ACG TTC CTG ATG CT-3' (Metabion, Martinsried, Germany). Stimulation led to upregulation of costimulatory molecules (CD80, CD86, CD40) on the cell surface of DC (data not shown). A total of $1 \times 10^{4} \mathrm{BM}-\mathrm{DC} /$ well and $5 \times 10^{4}$ $\mathrm{CD}^{+} \mathrm{CD} 2 \mathrm{~L}^{+}$cells/well were cocultured in complete media containing $10 \mathrm{U} / \mathrm{ml} \mathrm{IL-2} \mathrm{(Chiron,} \mathrm{Munich,} \mathrm{Germany)} \mathrm{in} 96$ well plates precoated with $10 \mu \mathrm{g} / \mathrm{ml}$ anti-CD3. Cocultures were incubated for seven days and subjected to Ficoll (Fisher Scientific, Schwerte, Germany) to remove dead cells. Live cells $\left(5 \times 10^{4}\right)$ were restimulated on plate bound anti-CD3 $(2.5 \mu \mathrm{g} /$ $\mathrm{ml})$ with soluble anti-CD28 $(1 \mu \mathrm{g} / \mathrm{ml})$ for another 48 hours and supernatants were harvested for analysis.

\section{Histology}

Tissue was harvested from each animal, embedded in paraffin, and stained with haematoxylin-eosin after sectioning. To quantify tissue damage, a scoring system was used as described previously. ${ }^{521}$ An average score for the whole section was assigned based on a 0-4 scoring system, with emphasis on the inflammatory infiltrates of the mucosa and epithelial and mucosal damage. Sections were evaluated in a blinded fashion by two independent investigators.

\section{Cytokine ELISA of MLN cells and splenic lymphocytes}

Different splenic T cell populations were isolated as described above. Mesenteric lymph node (MLN) cells were collected under sterile conditions in ice cold medium, mechanically disrupted, and the cell suspension was filtered through a cell strainer $(70 \mu \mathrm{m})$. Tissue culture plates were coated in part with anti-CD3 $(2.5 \mu \mathrm{g} /$ well $)$, and $2 \times 10^{5}$ cells/well were incubated in $200 \mu \mathrm{l}$ of complete medium for 24 hours. Cytokine levels were measured in the supernatant by enzyme linked immunosorbent assay (ELISA) (all from Endogene, Woburne, Massachusetts, USA, except ELISA for transforming growth factor $\beta 1$ (TGF- $\beta 1$ ) from Biosource, Solingen, Germany), according to the manufacturer's instructions.

\section{Proliferation assay}

MLN cells were isolated as described above and cultured for 48 hours in medium in the presence of soluble anti-CD28 $(1 \mu \mathrm{g} / \mathrm{ml})$ and plate bound anti-CD3 $(2.5 \mu \mathrm{g} / \mathrm{ml})$ as well as $10 \mathrm{U} / \mathrm{ml} \mathrm{IL}-2$. Cells were pulsed for the last 16 hours of the incubation time with ${ }^{3}[\mathrm{H}]$-thymidine $(0.5 \mu \mathrm{Ci} /$ well $)$ and proliferation was measured using a liquid scintillation counter.

\section{Quantitative reverse transcription-polymerase chain reaction (RT-PCR) (Light cycler)}

Colonic tissue specimens and $\mathrm{CD}^{+} \mathrm{CD} 62 \mathrm{~L}^{+}$as well as $\mathrm{CD}^{+} \mathrm{CD} 2 \mathrm{~L}^{-}$lymphocytes were harvested and mRNA was extracted using the RNeasy kit (Qiagen, Hilden, Germany) following the manufacturer's recommendations. mRNA was transcribed (Promega, Mannheim, Germany) and quantification of cytokine mRNA within colonic tissue samples was performed using a Light cycler (Roche Molecular Systems, Mannheim, Germany). For standardisation, $\beta$-actin was amplified. The following primer pair was used for amplification of the tumour necrosis factor $\alpha$ (TNF- $\alpha$ ) message: $5^{\prime}$ GCG ACG TGG AAC TGG CAG AAG-3' and 5'GGT ACA ACC CAT CGG CTG GCA- $3^{\prime}$, annealing temperature $62^{\circ} \mathrm{C}, 3 \mathrm{mM}$ $\mathrm{MgCl}_{2}$

Qualitative PCR for Foxp3 was performed with mRNA derived from different lymphocyte populations using the following primer pair: 5'-CAG CTG CCT AGA GTG CCC CTA G-3' and 5'-CAT TTG CCA GCA GTG GGT AG-3', annealing temperature $60^{\circ} \mathrm{C}, 3 \mathrm{mM} \mathrm{MgCl} 2$. 

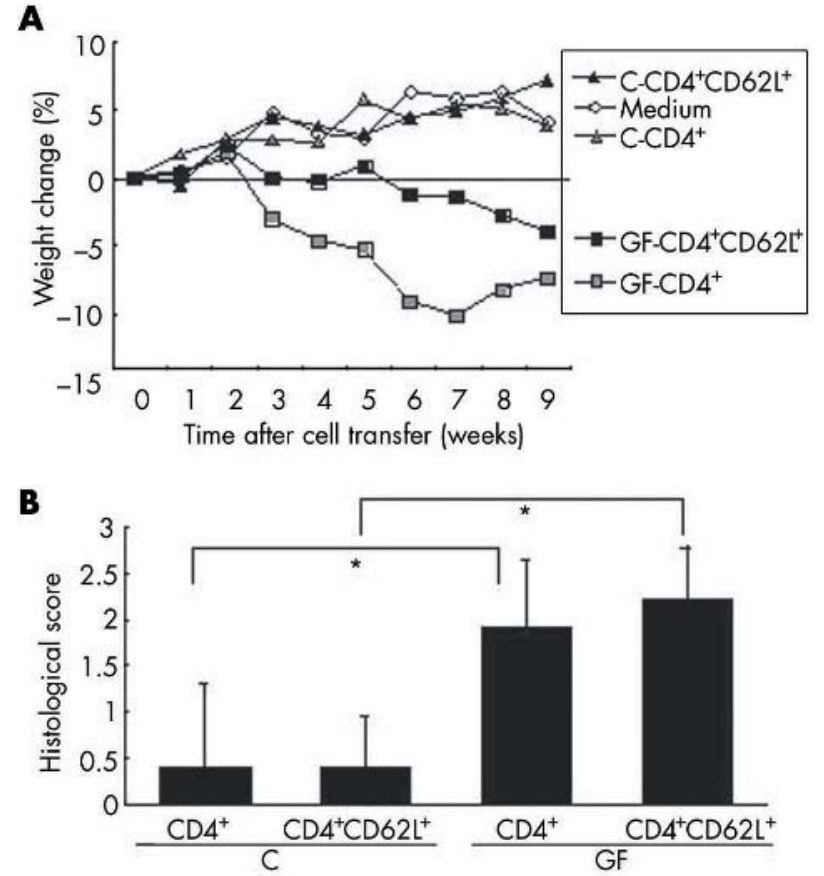

C

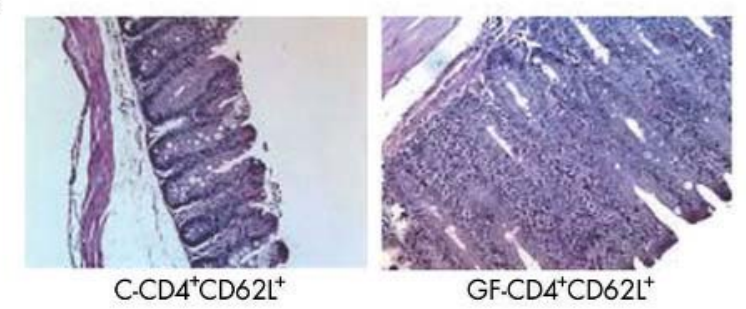

Figure 1 Earlier onset of colitis after transfer of $\mathrm{CD} 4^{+}$and $\mathrm{CD} 4^{+} \mathrm{CD} 62 \mathrm{~L}^{+}$ $T$ cells derived from germ free (GF) animals compared with conventionally (C) housed mice into SCID animals. (A) Changes in weight were monitored over time and are shown as weekly percentage of changes in weight from baseline. (B) Histological score was determined at the end of week 9 , as described in the methods section. Values are mean (SD). ${ }^{*} p<0.05$ versus mice that received cells from conventional donors. (C) Representative colonic haematoxylin-eosin sections from both animal groups are shown (magnification 100 $\times$ ). Data are representative of three independent experiments, $n=5$ mice per group.

\section{FACS analysis}

Samples were analysed using two colour staining. Briefly, isolated lymphocytes were preincubated with $20 \mu \mathrm{g} / \mathrm{ml}$ of the Fc $\gamma$ III/II receptor antibody anti-CD16/CD32 to block murine Fc-receptors and stained with both FITC and PE conjugated antibodies. Cells were washed and analysed by FACS using an EPICS-XL MCL Coulter.

\section{Statistics}

Statistical analysis was performed using the Student's $t$ test (cytokine levels) and the Mann-Whitney U test for unpaired samples (histological score). Error bars represent the standard error (histological score) or the standard error of the mean (cytokine levels, proliferation). Differences were considered statistically significant when $\mathrm{p}<0.05$.

\section{RESULTS}

Transfer of CD4 ${ }^{+}$CD62L $L^{+}$lymphocytes from germ free mice induces early onset of severe colitis

In order to investigate whether the gut flora of donor mice is necessary to prime $\mathrm{T}$ cells to mediate intestinal inflammation within the transfer model of colitis, lymphocytes were isolated either from donor animals that were housed in a
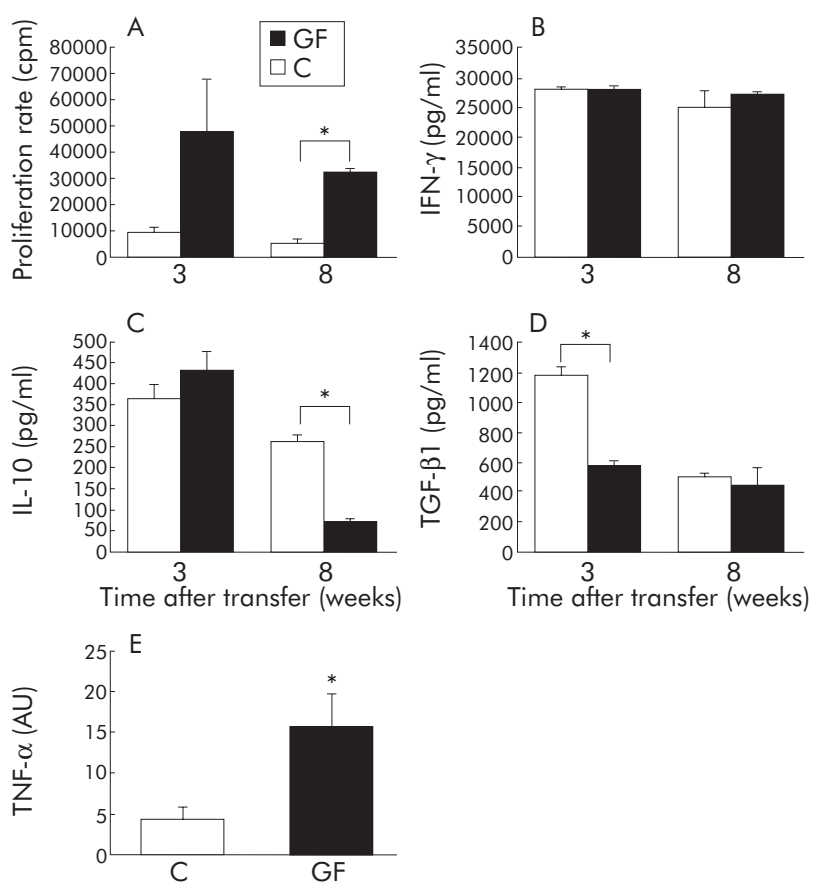

Figure 2 Comparison of cytokine production and proliferation of mesenteric lymph node (MLN) cells from animals reconstituted with cells derived from germ free (GF) or conventionally (C) housed mice. (A) $\mathrm{CD}^{+} \mathrm{CD} 62 \mathrm{~L}^{+}$cells from GF and $\mathrm{C}$ donor mice were transferred into SCID recipients and MLN from 3-4 animals from each group were harvested three and eight weeks after transfer. MLN cells were isolated from pooled organs and incubated for 48 hours. Thymidine was added for the last 16 hours of the incubation time and proliferation was measured. (B-D) Additionally, pooled MLN cells from 3-4 animals in each group derived from animals three and eight weeks after transfer were incubated in quadruplicate cultures for 24 hours in the presence of plate bound anti-CD3. Cytokine concentrations of interferon $\gamma$ (IFN- $\gamma$ ) (B), interleukin 10 (IL-10) (C), and transforming growth factor $\beta 1$ (TGF- $\beta 1$ ) (D) were measured in supernatants by enzyme linked immunosorbent assay. (E) Total RNA was isolated from individual colonic tissue at the end of the experiment ( $n=5$ mice per group), transcribed, and specific mRNA of the proinflammatory cytokine tumour necrosis factor $\alpha$ (TNF- $\alpha$ ) was quantified using a Light cycler.

conventional environment or under GF conditions. After reconstitution with the different cell populations, SCID mice were monitored for clinical signs of colitis and weight change. Unexpectedly, animals that received lymphocytes from GF donors started to loose weight and developed diarrhoea and anal prolapse by 3-4 weeks after transfer, showing a very early onset of intestinal inflammation (fig 1A). On the other hand, mice reconstituted with T cells isolated from conventionally housed animals initially gained weight and slowly developed clinical signs of colitis. Histological analysis confirmed a more pronounced colitis and severe tissue damage in mice that received cells from GF mice than in animals repopulated with cells from conventional donors (fig 1B, 1C).

\section{MLN cells differ between recipients of lymphocytes from germ free or conventionally housed mice regarding proliferative potential and cytokine secretion}

In order to further characterise differences in colitis severity, we compared cytokine secretion and proliferation of infiltrating lymphocytes in both groups. Therefore, MLN of diseased animals were harvested three weeks after transfer or at the end of the experiment. Cytokine secretion within the supernatant of MLN cells was measured and proliferation of 

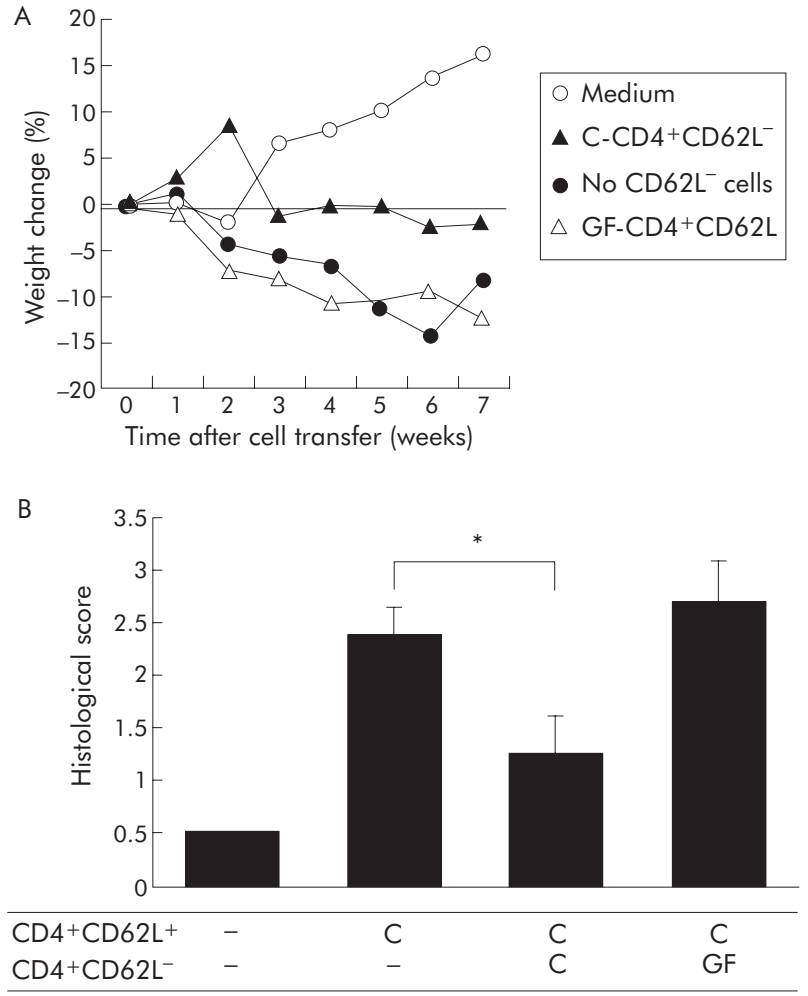

Figure $3 \mathrm{CD}^{+} \mathrm{CD} 6 \mathrm{~L}^{-} \mathrm{T}$ lymphocytes from germ free (GF) animals were unable to protect from colitis. Equal numbers of $C D 4^{+} C D 62 L^{-} T$ cells from GF or conventional (C) donor mice were cotransferred with $\mathrm{CD}^{+} \mathrm{CD} 62 \mathrm{~L}^{+}$lymphocytes derived from conventionally housed animals into SCID recipients. $(A)$ Weight changes were monitored over time and are shown as percentage of weekly changes compared with baseline. Labelling indicates the additional cotransferred lymphocyte population. (B) Histological scores were determined at the end of week 7, as described in the methods section. Data are representative of three independent experiments, $n=5$ mice per group. Values are mean (SD) ${ }^{*} \mathrm{p}<0.05$, significantly different from mice that received only cells from conventionally housed donors without cotransferred lymphocytes.

isolated lymphocytes was determined by thymidine incorporation.

As shown, MLN cells from animals reconstituted with cells from GF donors showed at both time points a significantly higher proliferative potential after in vitro stimulation than cells from SCID mice that received lymphocytes from conventionally housed animals (fig 2A).

When cytokine levels within the supernatant were analysed, MLN cells from both groups produced high amounts of the proinflammatory cytokine interferon $\gamma(\mathrm{IFN}-\gamma)$ at the early as well as at the late time point. On the other hand, significantly higher levels of IL-10 were detected at the end of the experiment secreted by MLN cells from recipients of conventional donor cells compared with lymphocytes from recipients of GF donors. No differences in secretion of IL-10 were observed at the earlier time point. Additionally, measurement of TGF- $\beta 1$ revealed higher levels of this immunmodulatory cytokine within the supernatant of conventional MLN lymphocytes at this time point compared with GF cells, whereas no differences could be detected at eight weeks after transfer (fig 2B-D).

Using Light cycler PCR, significantly higher mRNA levels of the proinflammatory cytokine TNF- $\alpha$ were found within intestinal tissue harvested from animals that received GF lymphocytes than in tissue from mice reconstituted with conventional cells (fig 2E).
A

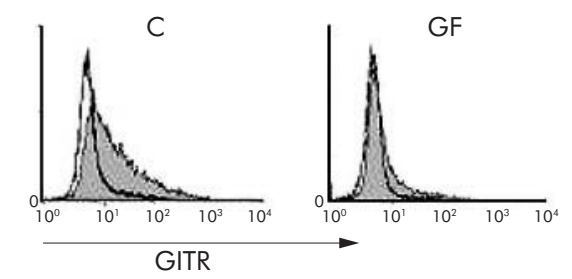

B

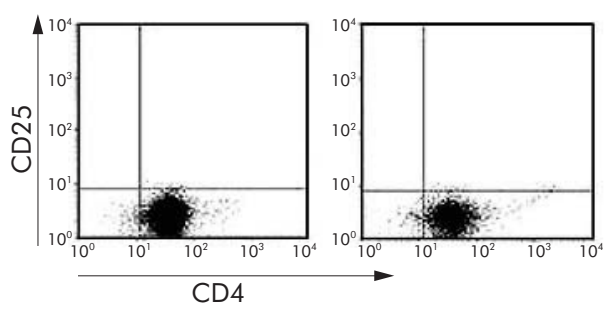

Figure 4 FACS analysis of $C D 4^{+} C D 62 \mathrm{~L}^{+}$lymphocytes from germ free (GF) and conventionally (C) housed mice. CD4 ${ }^{+} \mathrm{CD} 62 \mathrm{~L}^{+} \mathrm{T}$ cells were isolated, and FACS analysis for expression of glucocorticoid induced tumour necrosis factor receptor related protein (GITR) and CD25 was performed. (A) GITR staining of lymphocytes from $C$ housed mice and GF animals. The isotype control is indicated as the unfilled line. (B) Lack of CD25 expression by CD $4^{+} C D 62 L^{+} T$ cells derived from both groups of mice. A representative of four separate analyses is shown.

\section{$\mathrm{CD}^{+}{ }^{+} \mathrm{CD} 62 \mathrm{~L}^{-}$lymphocytes from germ free mice are unable to prevent colitis after cotransfer with CD4 ${ }^{+} \mathrm{CD} 62 \mathrm{~L}^{+}$cells}

As shown previously, $\mathrm{CD} 4^{+} \mathrm{CD} 45 \mathrm{RB}^{\text {low }} \mathrm{T}$ cells can prevent almost completely the development of intestinal inflammation induced by transfer of $\mathrm{CD} 4^{+} \mathrm{CD} 45 \mathrm{RB}^{\text {high }}$ lymphocytes. ${ }^{11}$ In order to investigate whether the $\mathrm{CD}^{+} \mathrm{CD} 62 \mathrm{~L}^{-} \mathrm{T}$ cell population derived from GF mice would inhibit the colitis inducing potential of $\mathrm{CD}^{+} \mathrm{CD}_{2} \mathrm{~L}^{+}$lymphocytes from normal donor animals, both cell populations were cotransferred into recipient mice. As indicated in fig $3 \mathrm{~A}$, animals receiving only $\mathrm{CD} 4^{+} \mathrm{CD} 62 \mathrm{~L}^{+}$lymphocytes lost weight whereas, as expected, additional transfer of $\mathrm{CD}^{+} \mathrm{CD} 62 \mathrm{~L}^{-}$lymphocytes from conventionally housed animals abrogated the weight loss. On the other hand, $\mathrm{CD}^{+} \mathrm{CD} 2 \mathrm{~L}^{-}$cells from GF mice were unable to inhibit the development of colitis after cotransfer. The histological score reflected the clinical results and showed significantly reduced inflammation when CD62 $\mathrm{L}^{-}$lymphocytes from conventionally housed mice were cotransferred and an unaffected severe colitis after additional reconstitution of animals with $\mathrm{CD} 4{ }^{+} \mathrm{CD} 62 \mathrm{~L}^{-}$cells from GF mice (fig 3B).

\section{CD4 ${ }^{+}$CD $62 L^{+}$T cells from conventional housed mice} contain a significant population of GITR $^{+}$lymphocytes To analyse whether the functional differences between CD62 $\mathrm{L}^{+}$and $\mathrm{CD} 6 \mathrm{~L}^{-}$cell populations of conventional and GF animals within our experiments would be reflected by phenotypic differences regarding various cell surface markers, FACS analysis was carried out. We focused on detection of molecules that had been described previously to characterise $T_{\text {reg }}$ lymphocytes. No difference in expression of CTLA-4, a negative costimulatory molecule that had been demonstrated to be expressed by $\mathrm{T}_{\text {reg }}$ cells, was seen. Additionally, CD25, the IL-2 receptor known to characterise an important regulatory $\mathrm{T}$ cell subset, was not detected on the cell surface of $\mathrm{CD} 2 \mathrm{~L}^{+}$lymphocytes from different housed donor mice (fig 4) and was similarly low on both CD62 $\mathrm{L}^{-} \mathrm{T}$ cell groups.

However, expression of GITR, a receptor that had been suggested as a specific marker for $\mathrm{T}_{\text {reg }}$ cells and was shown to attenuate suppressive activity of $\mathrm{CD} 25^{+} \mathrm{CD} 4^{+} \mathrm{T}_{\text {reg }}$ cells when 

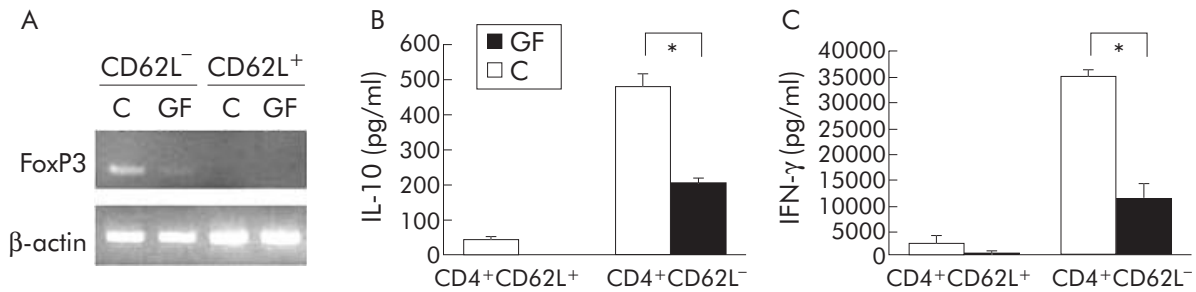

Figure 5 FoxP3 expression and functional analysis of $C D 4^{+} C D 62 L^{+}$and $C D 4^{+} C D 62 L^{-}$lymphocytes from germ free (GF) and conventionally (C) housed mice. (A) $\mathrm{CD} 4^{+} \mathrm{CD} 62 \mathrm{~L}^{+}$and $\mathrm{CD} 4^{+} \mathrm{CD} 62 \mathrm{~L}^{-}$lymphocytes from $\mathrm{C}$ and $\mathrm{GF}$ housed animals were isolated and reverse transcription-polymerase chain reaction analyses were conducted for expression of Foxp3 and $\beta$-actin. Data are representative of three independent experiments.

(B, C) Additionally, CD4 $4^{+} \mathrm{CD} 62 \mathrm{~L}^{+}$and $\mathrm{CD} 4^{+} \mathrm{CD} 62 \mathrm{~L}^{-} \mathrm{T}$ cells from GF or $\mathrm{C}$ donor mice were incubated in quadruplicate cultures for 24 hours on plate bound anti-CD3 and cytokine concentrations of interleukin 10 (IL-10) and interferon $\gamma$ (IFN- $\gamma$ ) were measured in supernatants by enzyme linked immunosorbent assay. Data are representative of four independent experiments. Values are mean (SEM). ${ }^{*} p<0.05$, significant difference between data received from $T$ lymphocytes derived from GF mice compared with $C$ animals.

activated, ${ }^{22}$ differed between $\mathrm{CD} 4{ }^{+} \mathrm{CD} 62 \mathrm{~L}^{+}$cells derived from conventional mice and lymphocytes from GF animals (fig 4) whereas there was no difference in GITR expression on the cell surface of different $\mathrm{CD} 6 \mathrm{~L}^{-} \mathrm{T}$ cells (data not shown).

\section{$\mathrm{CD}^{+}{ }^{\mathrm{CD}} 62 \mathrm{~L}^{-}$lymphocytes from germ free mice} secrete lower levels of IL-10 and IFN- $\gamma$

To further investigate differences between the lymphocyte populations, $\mathrm{CD} 4^{+}$subsets were stimulated in vitro and cytokine secretion within the supernatant was measured. $\mathrm{CD}^{+} \mathrm{CD} 62 \mathrm{~L}^{+}$and $\mathrm{CD} 62 \mathrm{~L}^{-}$lymphocytes derived from mice with intact bacterial gut flora produced more of the antiinflammatory cytokine IL-10 than identical cell subsets from GF animals (fig 5B). Overall, as expected, due to their proposed higher frequency of $\mathrm{T}_{\text {reg }}$ cells, $\mathrm{CD} 2 \mathrm{~L}^{-}$lymphocytes from both groups of donors secreted higher quantities of IL-10 than "naïve" $\mathrm{CD} 4{ }^{+} \mathrm{CD} 62 \mathrm{~L}^{+}$lymphocytes derived from the same animals. However, the $\mathrm{CD}^{2} 2 \mathrm{~L}^{-} \mathrm{T}$ cell population from conventionally housed mice produced more than twice as much of the cytokine that is known to be a key mediator of $\mathrm{T}_{\text {reg }}$ effects than cells from GF animals (fig 5B). On the other hand, when IFN- $\gamma$-levels were measured, lymphocyte subsets from conventionally housed animals also released higher amounts of the proinflammatory cytokine when stimulated than cells from GF mice (fig 5B). No significant levels of TGF- $\beta 1$, another cytokine with regulatory function, could be detected within the supernatants of either cell population (data not shown).

\section{$\mathrm{CD} 4{ }^{+} \mathrm{CD} 62 \mathrm{~L}^{-}$lymphocytes from germ free mice show lower expression levels of Foxp3}

Foxp3 is a recently described transcription factor associated with the development of regulatory T cells. As shown, natural regulatory $\mathrm{CD}^{+} \mathrm{CD}_{2} 5^{+}$lymphocytes express Foxp3 by RT-PCR whereas other regulatory $\mathrm{T}$ cell subsets such as Trl-like cells are thought to be negative. ${ }^{23}$ Freshly purified $\mathrm{CD}^{+} \mathrm{CD} 6 \mathrm{~L}^{-}$splenocytes from conventionally housed animals express Foxp3, as shown in fig 5A. When cell subsets from GF animals were investigated, $\mathrm{CD}^{+} \mathrm{CD} 62 \mathrm{~L}^{-}$lymphocytes expressed dramatically lower levels of the transcript, suggesting that indeed a lower number of regulatory Foxp3 expressing $\mathrm{T}^{\mathrm{reg}}$ cells are present in the cell population from GF mice. On the other hand, $\mathrm{CD} 4{ }^{+} \mathrm{CD} 62 \mathrm{~L}^{+}$splenocytes from both groups of mice did not show constitutive levels of Foxp3mRNA (fig 5A).

\section{Differences in polarisation of $\mathrm{CD4}{ }^{+} \mathrm{CD} 62 \mathrm{~L}^{+}$ lymphocytes from germ free or conventional housed animals by BM-DC}

To determine whether $\mathrm{CD} 4{ }^{+} \mathrm{CD} 62 \mathrm{~L}^{+}$lymphocytes from GF and conventionally housed mice differed in their differentiation potential, cocultures of $\mathrm{CD} 4^{+} \mathrm{CD} 62 \mathrm{~L}^{+}$splenic $\mathrm{T}$ cells
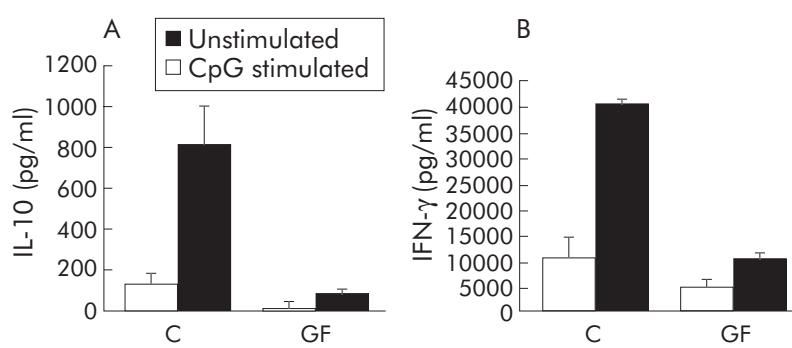

Figure $6 \mathrm{CD}^{+} \mathrm{CD} 6 \mathrm{~L}^{+} \mathrm{T}$ cells from conventionally $(\mathrm{C})$ housed mice secrete higher levels of interleukin 10 (IL-10) after coculture with stimulated bone marrow derived dendritic cells (BM-DC) than lymphocytes from germ free (GF) animals. $C D 4^{+} C D 62 L^{+} T$ cells were isolated from both animal groups and cultured with unstimulated or $\mathrm{CpG}$ stimulated BM-DC for seven days, followed by restimulation of $T$ lymphocytes in quadruplicate cultures with plate bound anti-CD3 and soluble anti-CD28 for 48 hours. Interleukin 10 (IL-10) (A) and interferon $\gamma($ IFN- $\gamma$ ) (B) levels were measured in the supernatant of T cells by enzyme linked immunosorbent assay. Data are representative of three independent experiments. Values are mean (SEM). ${ }^{*} p<0.05$, significant difference between data received from $\mathrm{T}$ lymphocytes derived from GF mice compared with $\mathrm{C}$ animals.

previously derived from conventionally housed animals or GF mice with unstimulated and CpG stimulated BM-DC, as antigen-presenting cells, were initiated. After coculture, lymphocytes were restimulated in the absence of BM-DC and supernatants were assayed for IFN- $\gamma$ as well as for the anti-inflammatory cytokine IL-10. As shown in fig 6, unstimulated BM-DC were able to induce $\mathrm{T}$ cells from conventionally housed mice to secrete high levels of IFN- $\gamma$ and IL-10. The effect was even more pronounced when BM-DC were activated with CpG. On the other hand, lymphocytes from GF mice released significantly reduced amounts of both cytokines compared with cells from donors with regular bacterial flora.

\section{DISCUSSION}

Antigens derived from the intestinal bacterial flora and other bacterial products are involved in chronic gut inflammation. ${ }^{724}$ In this study, we have extended previous findings as our data have also demonstrated a crucial role for the bacterial flora under healthy conditions within the generation of regulatory mechanisms for peripheral immunological homeostasis.

Using an adoptive transfer model we were able to show that $\mathrm{CD} 4{ }^{+} \mathrm{CD} 62 \mathrm{~L}^{+}$lymphocytes derived from GF mice induce an earlier onset and more severe colitis than cells from conventionally housed mice, indicating that GF T cells exhibit a more pathogenic potential than lymphocytes from regularly 
housed animals. This observation could be explained by two different mechanisms: (1) in conventionally housed animals, lymphocytes that react towards luminal antigens are eliminated in the periphery by deletion or anergy in order to preserve intestinal homeostasis. However, within the immunological pool of GF mice, these cells are not eliminated. Therefore, transferred $\mathrm{CD}^{+} \mathrm{CD} 2 \mathrm{~L}^{+}$cells could still contain lymphocytes with potential cross reactivity against bacterial antigens of the normal gut flora that subsequently induce severe colitis; (2) exposure to bacterial antigens induces the generation or expansion of antigen specific or thymus derived $\mathrm{T}_{\text {reg }}$ cells that control pathogenic responses driven by resident bacteria under healthy conditions. GF lymphocytes would lack these $\mathrm{T}_{\text {reg }}$ cells.

Our results support the second hypothesis. As shown, $\mathrm{CD}^{+} \mathrm{CD} 62 \mathrm{~L}^{+}$lymphocytes from conventional animals produced high levels of IL-10 after in vitro priming whereas this anti-inflammatory cytokine was almost undetectable within the supernatant of cells from GF mice. This observation suggests that the differences seen after cell transfer are likely propagated by the presence of an IL-10 secreting cell subset with regulatory function in the lymphocyte mixture derived from conventional animals that delays the onset of intestinal inflammation in recipient animals. Surprisingly, production of the proinflammatory cytokine IFN- $\gamma$ by lymphocytes from conventional animals was also slightly higher than within the supernatant of GF mice. However, it was shown previously that secretion of IFN- $\gamma$ by $\mathrm{T}_{\text {reg }}$ cells does not differ from Th0 clones. ${ }^{25}{ }^{26}$ This suggests that elevated levels of IFN- $\gamma$ within the supernatant of lymphocytes from conventional animals do not argue against the hypothesis of a higher percentage of $\mathrm{T}_{\text {reg }}$ cells within the $\mathrm{CD}^{+} \mathrm{CD} 2 \mathrm{~L}^{+}$ subpopulation of these mice.

Specific subsets of $\mathrm{CD}^{+}$lymphocytes have been implicated to act as regulatory cells. ${ }^{27-29}$ An important $T_{\text {reg }}$ population was described that expresses CD25 as defining phenotypic marker. ${ }^{3031} \mathrm{CD}^{+} \mathrm{CD} 25^{+} \mathrm{T}_{\text {reg }}$ cells are naturally present in naïve animals and thought to be generated within the thymus as a functional mature population..$^{32}{ }^{33}$ In addition, CTLA-4 is highly expressed by some $\mathrm{T}_{\mathrm{reg}}$ cells and the TNF receptor family member GITR identifies another small subset of cells with regulatory capacity. ${ }^{34}$ Interestingly, the GITR receptor had been suggested previously as a specific marker for $\mathrm{T}_{\text {reg }}$ cells that control intestinal inflammation as $\mathrm{CD}^{+} \mathrm{GITR}^{+}$lymphocytes were able to prevent colitis in the transfer model, independent of additional expression of the CD25 receptor..$^{34}$ Furthermore, the unique transcription factor Foxp3 has been identified recently as being required for generation of natural $\mathrm{T}_{\text {reg }}$ cells. ${ }^{35}$ However, not all $\mathrm{T}$ cells with regulatory function seem to express Foxp3, as Trl-like lymphocytes are negative for the transcription factor. ${ }^{23}$

Although $\mathrm{CD}^{+} \mathrm{CD}_{2} \mathrm{~L}^{+}$lymphocytes from conventional and GF animals lack expression of CD25 or CTLA-4, and Foxp3 was not detected by RT-PCR, we were able to detect cell surface levels of GITR on a higher percentage of $\mathrm{CD}^{+} \mathrm{CD} 62 \mathrm{~L}^{+} \mathrm{T}$ cells from conventional animals compared with lymphocytes from GF mice. This observation suggests that a significant population of $\left(\mathrm{GITR}^{+}\right) \mathrm{T}_{\text {reg }}$ cells reside within the $\mathrm{CD}^{+} \mathrm{CD} 2 \mathrm{~L}^{+}$subset of lymphocytes from normal mice. The higher percentage of these cells in conventional animals compared with GF mice suggests the generation of these cells within the periphery in response to bacterial antigens.

To confirm the assumption that lymphocytes from GF mice would contain a lower frequency of regulatory lymphocytes, cotransfer of $\mathrm{CD}^{+} \mathrm{CD} 62 \mathrm{~L}^{-} \mathrm{T}$ cells together with the $\mathrm{CD}^{+} \mathrm{CD} 2 \mathrm{~L}^{+}$subset of conventional mice was initiated. Indeed, cotransfer of $\mathrm{CD}^{+} \mathrm{CD}^{2} \mathrm{~L}^{-}$lymphocytes from conventional mice with pathogenic $\mathrm{CD}^{+} \mathrm{CD} 62 \mathrm{~L}^{+} \mathrm{T}$ cells abrogated colitis whereas equal numbers of $\mathrm{CD} 4^{+} \mathrm{CD} 62 \mathrm{~L}^{-}$ lymphocytes from GF donors were not able to prevent intestinal inflammation. Additionally, $\mathrm{CD} 4^{+} \mathrm{CD} 62 \mathrm{~L}^{-}$lymphocytes from conventional mice secreted more IL-10 than T cells from GF mice and showed higher expression of the $\mathrm{T}^{\mathrm{reg}}$ specific transcription factor Foxp3. This observation suggests the presence of a larger proportion of natural thymus derived $\mathrm{T}_{\text {reg }}$ cells within the lymphocyte subset of conventional animals.

Our observation is in agreement with a previous report that demonstrated that $\mathrm{CD}^{+} \mathrm{CD} 45 \mathrm{RB}^{\text {low }}$ lymphocytes from Helicobacter hepaticus infected donor animals were able to protect infected IL-10-deficient mice from colitis. It was explained by the generation of bacteria specific $\mathrm{T}_{\text {reg }}$ cells in response to colonisation with Helicobacter in healthy donor mice. ${ }^{36}$ On the other hand, in contrast with our data, it has been shown previously that $\mathrm{CD}^{+} \mathrm{CD} 45 \mathrm{RB}^{\text {low }} \mathrm{T}$ cells from GF mice were able to protect against colitis when transferred in high quantities, suggesting that this lymphocyte subset contains a $\mathrm{T}_{\text {reg }}$ population as well. ${ }^{37}$ Differences within the cellular composition of $\mathrm{CD} 4{ }^{+} \mathrm{CD} 62 \mathrm{~L}^{-}$and $\mathrm{CD} 4{ }^{+} \mathrm{CD} 45 \mathrm{RB}^{\text {low }}$ lymphocytes are most likely not the reason for this divergent observation as cell surface markers did not differ between the two lymphocyte groups (data not shown). Rather, cells from GF mice may contain small numbers of natural thymus derived $\mathrm{CD} 4^{+} \mathrm{CD} 25^{+} \mathrm{T}_{\text {reg }}$ subsets that do not need induction in response to bacterial stimulation, as suggested for adaptive $\mathrm{T}_{\text {reg }}$ subsets. Therefore, when high numbers of $\mathrm{CD} 4{ }^{+} \mathrm{CD} 45 \mathrm{RB}^{\text {low }}$ lymphocytes are cotransferred from GF donors, thymus derived $\mathrm{T}_{\text {reg }}$ lymphocytes within this cellular composition are able to prevent colitis.

In summary, we have demonstrated that continuous exposure to bacterial antigens induces regulatory $\mathrm{T}$ cell functions that protect from colitis in the first weeks after transfer of lymphocytes into immunodeficient hosts. $T_{\text {reg }}$ cells within the $\mathrm{CD} 4^{+} \mathrm{CD} 62 \mathrm{~L}^{+}$subset are likely to be different from classical $\mathrm{CD}^{+} \mathrm{CD} 25^{+}$and $\mathrm{CD} 4^{+} \mathrm{CTLA}-4^{+} \mathrm{T}_{\text {reg }}$ lymphocytes as the cells do not contain a significant subset of CD25 or CTLA-4 positive lymphocytes. However, a higher percentage of $\mathrm{CD}^{+} \mathrm{GITR}^{+}$cells and the production of large amounts of IL- 10 suggest the presence of functional $\mathrm{T}_{\text {reg }}$ cells within the $\mathrm{CD} 4{ }^{+} \mathrm{CD} 62 \mathrm{~L}^{+}$lymphocyte subset derived from normal mice. Additionally, as shown by a higher frequency of Foxp $3^{+}$cells within the $\mathrm{CD} 4^{+} \mathrm{CD} 62 \mathrm{~L}^{-}$lymphocyte subset, bacterial antigens seem to induce expansion of natural thymus derived $\mathrm{T}_{\text {reg }}$ cells.

These results indicate that enteric bacterial antigens are crucial for the generation and/or expansion of $\mathrm{T}_{\text {reg }}$ cells within peripheral tissues. Bacterial colonisation of a healthy individual is therefore of great importance to advise the immune system to generate regulatory mechanisms and maintain immunological homeostasis under normal conditions. These regulatory mechanisms would also be necessary to regain the immunological balance after initial proinflammatory answers towards pathogenic antigens in order to prevent chronicity of inflammation.

It is tempting to speculate that the higher incidence of IBD within industrial nations could be partly due to a "cleaner" environment that inhibits the generation of necessary intestinal regulatory mechanisms and could therefore, after triggering by a bacterial infection, lead to an overly aggressive chronic answer in a susceptible host.

\section{ACKNOWLEDGEMENTS}

This work was supported by grants from the German Research Foundation DFG (UGS, HCR, MM), as well as by research grants from the University of Regensburg, Germany, as part of the ReForMprogramme (UGS, FO). 


\section{Authors' affiliations}

U G Strauch, F Obermeier, N Grunwald, S Gürster, N Dunger,

M Schultz, J Schölmerich, H C Rath, Department of Internal Medicine I, University of Regensburg, Regensburg, Germany

D P Griese, Department of Internal Medicine II, University of Regensburg, Regensburg, Germany

M Mähler, Institute for Laboratory Animal Science and Central Animal Facility, Medical School Hannover, Hannover, Germany

Conflict of interest: None declared.

\section{REFERENCES}

1 Bouma G, Strober W. The immunological and genetic basis of inflammatory bowel disease. Nat Rev Immunol 2003;3:521-33.

2 Elson CO, Cong Y, Brandwein S, et al. Experimental models to study molecular mechanisms underlying intestinal inflammation. Ann N Y Acad Sci 1998:859:85-95.

3 Boismenu R, Chen Y. Insights from mouse models of colitis. J Leukoc Biol 2000;67:267-78.

4 Elson CO, Cong $\mathrm{Y}$, labal $\mathrm{N}$, et al. Immuno-bacterial homeostasis in the gut: new insights into an old enigma. Semin Immunol 2001;13:187-94.

5 Rath HC, Herfarth HH, lkeda JS, et al. Normal luminal bacteria, especially Bacteroides species, mediate chronic colitis, gastritis, and arthritis in HLAB27/human beta2 microglobulin transgenic rats. J Clin Invest 1996:98:945-53.

6 Sellon RK, Tonkonogy S, Schultz M, et al. Resident enteric bacteria are necessary for development of spontaneous colitis and immune system activation in interleukin-10-deficient mice. Infect Immun 1998;66:5224-31.

7 Cong Y, Brandwein SL, McCabe RP, et al. CD4+ T cells reactive to enteric bacterial antigens in spontaneously colitic C3H/HeJBir mice: increased T helper cell type 1 response and ability to transfer disease. J Exp Med 1998; 187:855-64.

8 Duchmann R, Marker-Hermann E, Meyer zum Buschenfelde KH. Bacteriaspecific T-cell clones are selective in their reactivity towards different enterobacteria or $\mathrm{H}$. pylori and increased in inflammatory bowel disease. Scand J Immunol 1996:44:71-9.

9 Duchmann R, Kaiser I, Hermann E, et al. Tolerance exists towards resident intestinal flora but is broken in active inflammatory bowel disease (IBD). Clin Exp Immunol 1995; 102:448-55.

10 Waidmann $M$, Allemand $Y$, Lehmann J, et al. Microflora reactive IL-10 producing regulatory $T$ cells are present in the colon of IL-2 deficient mice but lack efficacious inhibition of IFN-gamma and TNF-alpha production. Gut 2002;50:170-9.

11 Powrie F, Leach MW, Mauze S, et al. Phenotypically distinct subsets of CD4+ $\mathrm{T}$ cells induce or protect from chronic intestinal inflammation in C. B-17 scid mice. Int Immunol 1993;5:1461-71.

12 Powrie F, Correa-Oliveira R, Mauze S, et al. Regulatory interactions between CD45RBhigh and CD45RBlow CD4+ T cells are important for the balance between protective and pathogenic cell-mediated immunity. J Exp Med 1994; 179:589-600

13 Sadlack B, Merz H, Schorle H, et al. Ulcerative colitis-like disease in mice with a disrupted interleukin-2 gene. Cell 1993;75:253-61.

14 Taurog JD, Richardson JA, Croft JT, et al. The germfree state prevents development of gut and joint inflammatory disease in HLA-B27 transgenic rats. J Exp Med 1994; 180:2359-64.
15 Dianda L, Hanby AM, Wright NA et al. T cell receptor-alpha beta-deficient mice fail to develop colitis in the absence of a microbial environment. Am J Pathol 1997; 150:91-7.

16 Schultz M, Tonkonogy SL, Sellon RK, et al. IL-2-deficient mice raised under germfree conditions develop delayed mild focal intestinal inflammation. Am J Physiol 1999:276(6 Pt 1):G1461-72.

17 Aranda R, Sydora BC, McAllister PL, et al. Analysis of intestinal lymphocytes in mouse colitis mediated by transfer of CD4+, CD45RBhigh T cells to SCID recipients. J Immunol 1997; 158:3464-73.

18 Annacker O, Powrie F. Homeostasis of intestinal immune regulation. Microbes Infect 2002;4:567-74

19 Mudter J, Wirtz S, Galle PR, et al. A new model of chronic colitis in SCID mice induced by adoptive transfer of CD62L+CD4+ T cells: insights into the regulatory role of interleukin-6 on apoptosis. Pathobiology 2002;70:170-6.

20 Lutz MB, Kukutsch N, Ogilvie AL, et al. An advanced culture method for generating large quantities of highly pure dendritic cells from mouse bone marrow. J Immunol Methods 1999;223:77-92.

21 Rath HC, Schultz M, Freitag R, et al. Different subsets of enteric bacteria induce and perpetuate experimental colitis in rats and mice. Infect Immun $2001 ; 69: 2277-85$

22 Shimizu J, Yamazaki S, Takahashi T, et al. Stimulation of CD25(+)CD4(+) regulatory $T$ cells through GITR breaks immunological self-tolerance. Nat Immunol 2002;3:135-42.

23 Cobbold SP, Nolan KF, Graca L, et al. Regulatory T cells and dendritic cells in transplantation tolerance: molecular markers and mechanisms. Immunol Rev 2003;196:109-24.

24 Kishi D, Takahashi I, Kai Y, et al. Alteration of $\mathrm{V}$ beta usage and cytokine production of CD4+ TCR beta beta homodimer T cells by elimination of Bacteroides vulgatus prevents colitis in TCR alpha-chain-deficient mice. $\mathrm{J}$ Immunol 2000; 165:5891-9.

25 Groux H, O'Garra A, Bigler $M$, et al. A CD4+ T-cell subset inhibits antigenspecific T-cell responses and prevents colitis. Nature 1997;389:737-42.

26 Groux H. An overview of regulatory T cells. Microbes Infect 2001:3:883-9.

27 Garside P, Mowat AM, Khoruts A Oral tolerance in disease. Gut 1999;44:137-42

28 Shevach EM. Regulatory T cells in autoimmmunity. Annu Rev Immunol 2000; 18:423-49.

29 Shevach EM. CD4+ CD25+ suppressor T cells: more questions than answers. Nat Rev Immunol 2002;2:389-400.

30 Asano M, Toda M, Sakaguchi N, et al. Autoimmune disease as a consequence of developmental abnormality of a T cell subpopulation. J Exp Med 1996; 184:387-96.

31 Stephens LA, Mason D. CD25 is a marker for CD4+ thymocytes that prevent autoimmune diabetes in rats, but peripheral T cells with this function are found in both CD25+ and CD25- subpopulations. J Immunol 2000; 165:3105-10.

32 Jordan MS, Boesteanu A, Reed AJ, et al. Thymic selection of CD4+CD25+ regulatory $T$ cells induced by an agonist self-peptide. Nat Immunol $2001 ; 2: 301-6$

33 Bluestone JA, Abbas AK. Natural versus adaptive regulatory T cells. Nat Rev Immunol 2003;3:253-7.

34 Uraushihara K, Kanai T, Ko K, et al. Regulation of murine inflammatory bowel disease by CD25+ and CD25-CD4+ glucocorticoid-induced TNF receptor family-related gene+ regulatory T cells. J Immunol 2003;171:708-16.

35 Belkaid Y, Rouse BT. Natural regulatory T cells in infectious disease. Nat Immunol 2005;6:353-60.

36 Kullberg MC, Jankovic D, Gorelick PL, et al. Bacteria-triggered CD4(+) T regulatory cells suppress Helicobacter hepaticus-induced colitis. J Exp Med 2002;196:505-15

37 Singh B, Read S, Asseman C, et al. Control of intestinal inflammation by regulatory T cells. Immunol Rev 2001;182:190-200.

\section{1 th European Forum on Quality Improvement in Health Care}

26-28 April 2006, Prague, Czech Republic

For further information please go to: www.quality.bmipg.com

Book early to benefit from a discounted delegate rate 